\title{
Time-kill assay of pomegranate (punica granatum L) seed ethanolic extract against streptococcus sanguis; the cause of recurrent aphthous stomatitis
}

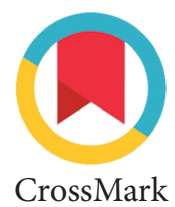

\author{
Riani Setiadhi, ${ }^{1 *}$ Irna Sufiawati, ${ }^{1}$ Dewi Zakiawati, ${ }^{1}$ Dani R. Firman ${ }^{2}$
}

\section{Abstract}

Objective: To examine the antimicrobial activity of pomegranate seed using a time-kill-assay by measuring the number of bacteria left at a various time points after exposure to the substance.

Material and Methods: Pomegranate seeds were extracted by a maceration method using $70 \%$ ethanol as the solvent. The extract was evaluated for minimum inhibitory concentration and minimum bactericidal concentration against streptococcus sanguis ATCC 10556, using a microdilution method. The concentration used in time-killassay were 2 to 4 times MBC value and 48 hours incubation time as the initial value. Correlation of the concentration and time duration using semi-log graph, i.e. the $x$-axis as time duration with variation interval of 30,60 and 90-seconds. Y-axis is the logarithmic value of the bacterial colonies number.

Results: Bacteriostatic effect was observed at $4000 \mathrm{ppm}$ concentration at 30,60 and 90-seconds time intervals. The bactericidal effect was observed at $8000 \mathrm{ppm}$ of concentration at the 90 -second time interval, whereas 30 and 60 -seconds remained bacteriostatic.

Conclusion: The pomegranate seeds ethanolic extract is considered as antibacterial with a concentration-dependent category.

Keywords: Pomegranate seeds, Streptococcus sanguis, Time-kill assay

Cite this Article: Setiadhi R, Sufiawati I, Zakiawati D, Firman DR. 2018. Time-kill assay of pomegranate (punica granatum L) seed ethanolic extract against streptococcus sanguis; the cause of recurrent aphthous stomatitis. Journal of Dentomaxillofacial Science 3(3): 152-155. DOl: $10.15562 / j \mathrm{jmfs} . v 3 \mathrm{i} 3.787$

${ }^{1}$ Department of Oral Medicine, Faculty of Dentistry, Padjadjaran University, Bandung, Indonesia 2Department of Oral Biology, Faculty of Dentistry, Padjadjaran University, Bandung, Indonesia

"Corresponding to: Riani Setiadhi, Department of Oral Medicine, Faculty of Dentistry, Universitas Padjadjaran, Bandung, Indonesia riani.setiadhi@fkg.unpad.ac.id

Received: 10 August 2018

Revised: 10 ctober 2018

Accepted: 7 November 2018

Available Online: 1 December 2018

\section{Introduction}

The pomegranate (punica granatum L.) is a versatile fruit that has many benefits such as improving health and is used as a traditional medicine. ${ }^{1}$ It contains high concentrations of phytonutrients and phytochemicals and it is rich in antioxidants and tannins. The main antioxidant in pomegranate is polyphenols, which contain flavonoids, tannins and vitamin C. Besides as antioxidant, flavonoids are antibacterial, antiviral, and anti-inflammatory too, while tannins have hemostatic, antibacterial and anti-inflammatory properties. ${ }^{2-4}$ The antibacterial flavonoid and tannin content in pomegranate is suspected to cope with streptococcus sanguis, also known as the bacteria that causes Recurrent Aphthous Stomatitis (RAS).

RAS, known as oral lesion, can occur at any part of the oral cavity accompanied with pain and may occur recurrently. It is a mild disease that is not life-threatening and can self-heal within 10-14 days without treatment but may interfere with eating and talking that can decrease the quality of life..$^{5-7}$ The aetiology of RAS is still unknown, but there are some predisposing factors which were thought to play an important role. Those factors are local factors, allergy, bacteria, immune status, haematinic, hormonal and psychological stress. ${ }^{5-9}$
The number of RAS incidence is about $10-25 \%$ in a population. It is quite a large number, and therefore it is relevant to many researchers to find the best treatment for RAS. ${ }^{8}$ One of the bacteria suspected to cause RAS is streptococcus sanguis and currently, an antiseptic mouthwash can be used for the treatment of this condition.

Mouthwash will contact with the oral mucosa for 30-60-seconds whereas the in vitro evaluation of the MBC against bacteria streptococcus sanguis done in 48 hours. Therefore, this requires a time-kill assay to optimize the contact time of the test extracts and bacteria. Time-kill assays are also known as the "suspension tests or suspension time-kill analysis" and are used to determine the time required by the antimicrobial agent to kill the microorganism. It is used in microbiology to assess a test object's in vitro antimicrobial activity in relation to time. ${ }^{10-19}$

\section{Material and Methods}

This experimental research was carried out in the Laboratory of Chemistry Padjadjaran University. The pomegranate fruits were collected from the region of Cisarua Lembang, dried under the sun, mashed it into powder and extracted by maceration method using $70 \%$ ethanol as the solvent. The extract was evaluated for Minimum Inhibitory Concentration (MIC) and Minimum Bacterial 


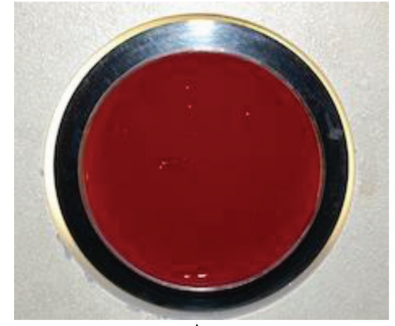

A

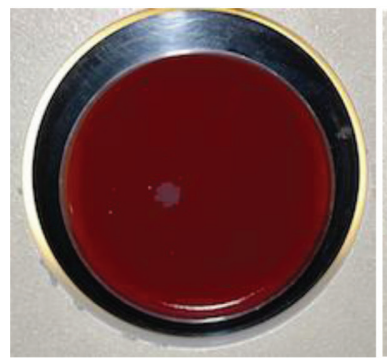

D

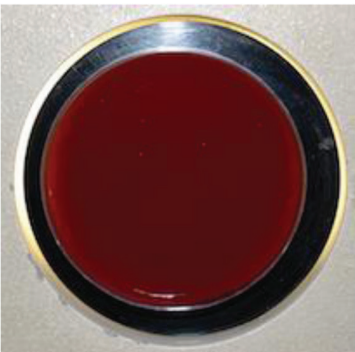

G

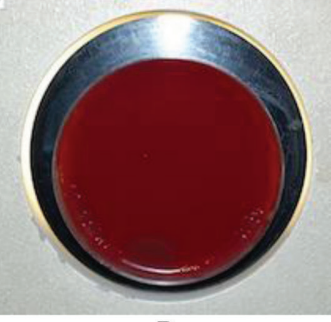

B

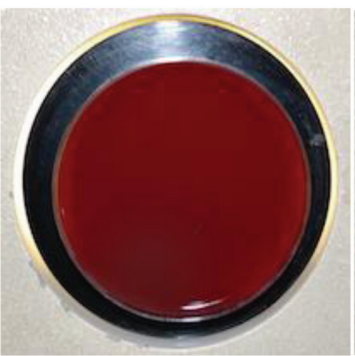

E

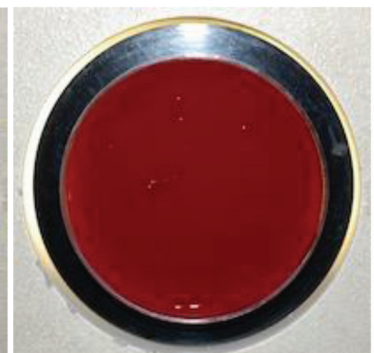

$\mathrm{H}$

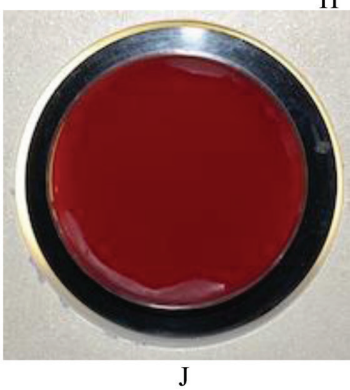

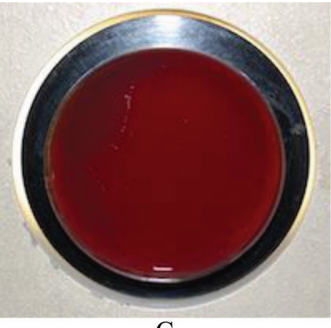

C

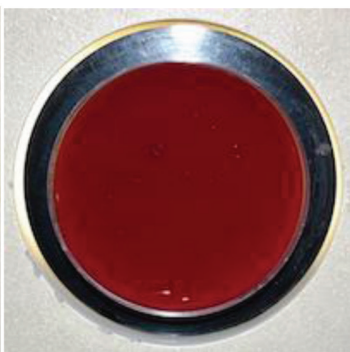

F

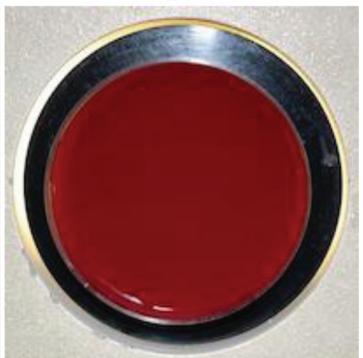

I

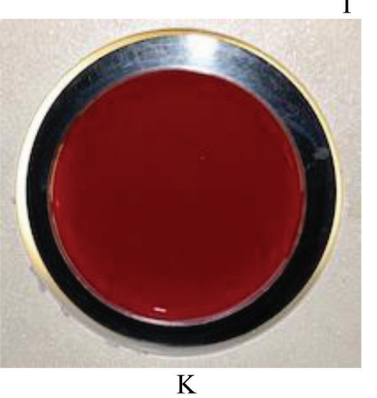

Figure 1 A. Colonies of S. sanguis $\left(1.3 \times 10^{6}\right)$ after 30 -seconds treatment with ethanol as the solvent, B. Colonies of S. sanguis $\left(13 \times 10^{5}\right)$ after $30-$ seconds treatment with pomegranate seeds ethanolic extract at the concentration of $4000 \mathrm{ppm}$ ( $2 \mathrm{x} \mathrm{MBC})$, C. Colonies of S. sanguis (10x10 $)$ after 30-seconds treatment with pomegranate seeds ethanolic extract at the concentration of $4000 \mathrm{ppm}(2 \mathrm{x}$ MBC), D. Colonies of S. Sanguis $\left(3 \times 10^{4}\right)$ after 60 -seconds treatment with pomegranate seeds ethanolic extract at the concentration of $4000 \mathrm{ppm}(2 \mathrm{x} \mathrm{MBC})$, E. colonies of S. sanguis $\left(2 \times 10^{5}\right)$ after 60 -seconds treatment with pomegranate seeds ethanolic extract at the concentration of $4000 \mathrm{ppm}(2 \mathrm{x} \mathrm{MBC}), \mathrm{F}$. Colonies of S. sanguis $\left(6 \times 10^{4}\right)$ after 90 -seconds treatment with pomegranate seeds ethanolic extract at the concentration of $4000 \mathrm{ppm}$ (2x MBC), G. Colonies of S. sanguis $\left(6 \times 10^{5}\right)$ after 90 -seconds treatment with pomegranate seeds ethanolic extract at the concentration of 4000 ppm (2x MBC), H. Colonies of S. sanguis $\left(11 \times 10^{5}\right)$ after 30 -seconds treatment with ethanol as the solvent, I. Colonies S. Sanguis $\left(1 \times 10^{5}\right)$ after 30-seconds treatment with pomegranate seeds ethanolic extract at the concentration of $8000 \mathrm{ppm}$ (4x MBC), J. Colonies S. sanguis $\left(1 \times 10^{4}\right)$ after 60-seconds treatment with pomegranate seeds ethanolic extract at the concentration of $8000 \mathrm{ppm}(4 \mathrm{x} \mathrm{MBC}), \mathrm{K}$. Colonies S. sanguis ( $\left.1 \times 10^{4}\right)$ after 90 -seconds treatment with pomegranate seeds ethanolic extract at the concentration of $8000 \mathrm{ppm}(4 \mathrm{x} \mathrm{MBC})$ concentration (MBC) against streptococcus sanguis ATCC 10556, using a microdilution method through a 96-well microplate. Dilution was carried out in stages starting from $8000 \mathrm{ppm}$ concentration. The obtained MBC value was the benchmark concentration for the time-kill-assay.

The extract was then prepared in concentrations 2 to 4 times the MBC value for the time-kill-assay. Samples were incubated at $37^{\circ} \mathrm{C}$ for 48 hours in an anaerobic state. This procedure was carried out for $30 \mathrm{sec}, 60 \mathrm{sec}$ and $90 \mathrm{sec}$, and then colonies of the growth bacteria were counted.

The intention is for the substance to be used as a mouthwash, therefore the duration of action for the test subject was planned accordingly. It was required to utilize a specific method that will represent the closest simulation on various exposure times.

To find out the correlation between concentration and time duration, semi-log graphs were used, i.e. the $\mathrm{x}$-axis as time duration, variation interval of 30, 60 and 90 -seconds. Y-axis is logarithmic value of the number of bacterial colonies. The results were the number of bacterial colonies present after an exposure at each concentration and each time interval.

\section{Results}

MIC of ethanolic extract pomegranate seeds against S. sanguis; pomegranate seeds ethanolic extract have bacteriostatic activity against bacteria streptococcus sanguis ATCC 10556 with a MIC of $2000 \mathrm{ppm}$ (at the 5th dilution). The MBC value of pomegranate seeds ethanolic extract against bacteria streptococcus sanguis was $2000 \mathrm{ppm}$, it showed that no occurrence of bacterial growth in the media at the minimum concentration.

Time-kill assays of $4000 \mathrm{ppm}$ and $8000 \mathrm{ppm}$ ethanolic extract pomegranate seeds; to determine the duration of action for the test subject that relevant with the intention for the substance to be used as a mouthwash, then it was required to utilize a specific method that will represent the closest simulation of the various exposure times.

Figure 1 shows the colony count of $S$. sanguis on blood agar plates. Plate A and $\mathrm{H}$ reveal the ethanolic solvent as solvent control colony of S. sanguis with the result was $10^{6}$ and similar result reveals by the negative control as well. Plates B and C show the bacterial colony count after the 30 -second intervention of time-kill assay for concentration of the sample $4000 \mathrm{ppm}(2 \mathrm{xMBC})$ was $10^{5}$. Plates of $\mathrm{D}$ and $\mathrm{E}$ show the 60 -second intervention of $4000 \mathrm{ppm}$ with a result $10^{4.5}$ and plates $F$ and $G$ show the 90 -second intervention at the same concentration with $10^{4.5} \mathrm{~S}$. sanguis colony as a result.

The higher concentration, which is $8000 \mathrm{ppm}$ as $4 \times \mathrm{xMBC}$ was tested on plate $\mathrm{I}, \mathrm{J}$ and $\mathrm{K}$ figure 1 , in 


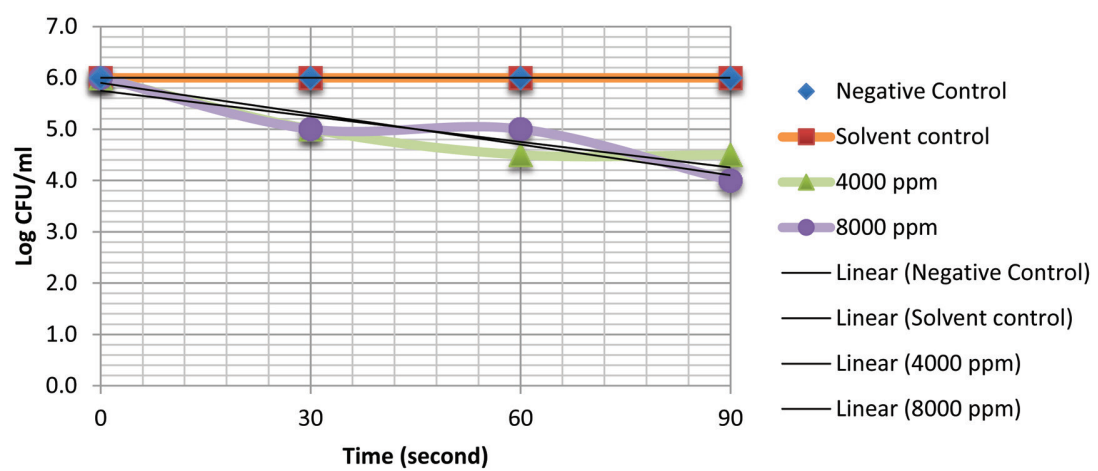

Figure 2 Linear regression comparison of the S. sanguis colonies count

$(\mathrm{CFU} / \mathrm{mL})$ after $30 \mathrm{~s}, 60 \mathrm{~s}$ and 90 s exposure time of the pomegranate seeds ethanol extract with $4000 \mathrm{ppm}, 8000 \mathrm{ppm}$ concentration and the negative control

Table 1 The colony count of the S. sanguis on the blood agar medium for $\mathbf{4 0 0 0} \mathrm{ppm}$ and $8000 \mathrm{ppm}$ based on the time of exposure interval 30s, $60 \mathrm{~s}$ and $90 \mathrm{~s}$

\begin{tabular}{lcccc}
\hline Time & Control (-) & Solvent Control & $\mathbf{4 0 0 0} \mathbf{~ p p m}$ & $\mathbf{8 0 0 0} \mathbf{~ p p m}$ \\
\hline 0 & 6.0 & 6.0 & 6.0 & 6.0 \\
30 & 6.0 & 6.0 & 5.0 & 5.0 \\
60 & 6.0 & 6.0 & 4.5 & 5.0 \\
90 & 6.0 & 6.0 & 4.5 & 4.0 \\
\hline
\end{tabular}

sequence 30, 60 and 90 -second. The results show $10^{5}, 10^{4}, 10^{4} \mathrm{~S}$. sanguis colony count in sequence. Based on the colonies count of the S. sanguis on the blood agar medium before, the data recapitulation is summarized in table 1 .

The table above shows duration of time contact between the $S$. sanguis and samples in sequence 30 , 60 and 90 -seconds. Then it was illustrated as a linear regression graph to clearly depict the decrease of the colonies count from each concentration and time of exposure as seen in figure 2.

Figure 2 shows linear regression as a way to illustrate a comparison of the $\mathrm{S}$. sanguis colonies count $(\mathrm{CFU} / \mathrm{ml})$ after $30 \mathrm{~s}, 60 \mathrm{~s}$ and 90 s exposure time of the pomegranate seeds ethanol extract with $4000 \mathrm{ppm}, 8000 \mathrm{ppm}$, and the negative control. Based on figure 2, the negative and solvent controls are shown as a straight line at the same level, which depict the same results. However, the 4000 ppm $(2 \mathrm{xMBC})$ with a green line and $8000 \mathrm{ppm}(4 \mathrm{xMBC})$ with a purple line, show different regression. The 90 -second contact duration time with $8000 \mathrm{ppm}$ (4xMBC) shown the lowest $S$. sanguis colony count, which is $10^{4}$ as a result.

\section{Discussion}

A time-kill assay at $4000 \mathrm{ppm}$ and $8000 \mathrm{ppm}$ ethanolic extract pomegranate seeds was used to determine the duration of action for the test subject with the intention for the substance to be used as a mouthwash. This required a specific method that will represent the closest simulation of various exposure times.

The time-kill assay uses concentrations of 2 to 4 times of incubation time MBC 48 hours as the initial value. To find out the correlation between concentration and time duration, a semi-log graph was be used, i.e. the $\mathrm{x}$-axis as time duration, variation interval of 30, 60 and 90-seconds. Y-axis is logarithmic value the number of bacterial colonies.

The $\mathrm{X}$ value is the number of colonies of S. sanguis $(\mathrm{CFU} / \mathrm{mL})$, with the value of the initial colonists prior to treatment (the interval of 0 -seconds) is in $\log 10 .^{6}$ Through a series of time intervals of 30, 60 and 90 -seconds, decrease in the number of results retrieved the colony to $4000 \mathrm{ppm}$ concentration $(2 \times M B C)$ i.e. the decline rate of $1.5 \times \log 10$ to interval duration of 30,60 and 90-seconds, whereas in concentration $8000 \mathrm{ppm}$ (4xMBC) obtained a decrease of up to 2 levels of $\log 10$ in the interval duration of 90 -seconds.

The pharmacodynamic aspects of antibacterial drugs include the nature of bacteriostatic or bactericide and also time-dependent or concentrationdependent. When a decrease of the number of bacterial colonies is $\geq 99.9 \%$ (two levels decrease of $\log 10)$ then the antibacterial effect can be categorized into the bactericidal, but if it is less, than these values are categorized as bacteriostatic. Time dependency is a category where the antibacterial effect is not affected even though the value of concentration continues to be raised. Only the duration of working time can affect the antibacterial effects. Concentration-dependency is a category for antibacterial activity that is unaffected by the duration of working time, which acts thus only based on the increase in concentration.

Based on the results of the time-kill assay obtained through linear regression graphs, the antibacterial test results clearly illustrated of its efficacy. At $4000 \mathrm{ppm}$ concentration, it is considered as bacteriostatic on the duration interval of $30 \mathrm{~s}$, 60s and 90s. Hence, for the 8000 ppm concentration, it was obtained that the existence of the effect of bactericide starts from the duration interval of 90 -seconds, whereas at 30 and 60 -seconds fixed categories include bacteriostatic. These finding suggest that the ethanol extract of pomegranate seeds was determined in the category of antibacterial concentration-dependent.

\section{Conclusion}

The present study was set out to examine the antimicrobial activity of pomegranate seed using a time kill assay, by measuring the number of bacteria 
left at a various time points that were relevant to the exposure time using by topical drug administration in the oral region. This study has identified that the ethanol extract of pomegranate seeds are a concentration-dependent antibacterial and proven for its potential. The implication of this finding suggests for further research for its potential efficacy of the substance on recurrent aphthous stomatitis therapy.

\section{Acknowledgment}

First of all, the authors would like to thank the Lord Almighty for given us the opportunity to complete this research and to the Dean of Faculty of Dentistry, Universitas Padjadjaran, who facilitated us with funding for this research, and to all staffs, laboratory workers at the chemical laboratory of the Faculty of Mathematics and Natural Sciences Universitas Padjadjaran, for helping us in conducting this research.

\section{Conflict of Interest}

All authors confirm that there is no conflict of interest associated with this publication.

\section{References}

1. Jurenka JS. Therapeutic Applications of Pomegranate (Punica granatum L.). Altern Med Rev 2008;13: 128-144.

2. Pereira JV, Pereira MSV, Sampo FC, et al. In vitro antibacterial and adherence effect of the extract of Punica gra-natum Linn. upon dental biofilm microorganisms. J Braz Pharmacogn 2006;16: 88-93.

3. Vasconcelos LC, Sampaio FC, Sampaio MC, et al. Minimum Inhibitory Concentration of Adherence of Punica granatum Linn (pomegranate) gel against S. mutans, S. mitis and C. albicans. Braz Dent J 2006;17: 223-227.

4. Viuda-Martos M, Fernandez-Lopez J, Perez-Alvarez JA. Pomegranate and its Many Functional Components as Related to Human Health: A Review. Comprehensive Reviews in Food Science and Food Safety. 2010; 9: 635-654.

5. Greenberg MS, Burket LW, Glick M. Burket's oral medicine: diagnosis \& treatment. Spain: BC Decker; 2003.

p. 63-65.
6. Preeti L, Magesh K, Rajkumar K, et al. Recurrent Aphthous Stomatitis. J Oral \& Maxillofac Pathol 2011;15: 252-256.

7. Scully C. Clinical practice. Aphthous ulceration. N Engl J Med 2006;355: 165-172.

8. Ship JA, Chavez EM, Doerr PA, et al. Recurrent aphthous stomatitis. Quintessence Int 2000;31: 95-112.

9. Beguerie JR, Sabas M. Recurrent aphthous stomatitis: an update on etiopathogenia and treatment. J Dermatol Nurses' Ass 2015; 7: 8-12.

10. Belley A, Neesham-Grenon E, Arhin FS, et al. Assessment by time-kill methodology of the synergistic effects of oritavancin in combination with other antimicrobial agents against staphylococcus aureus. ASM 2008;52: 3820-3822.

11. Rezaeian S, Attaran S, Pourianfar, HR. Time-kill kinetics and antibacterial activity of crude methanolic extract of thymus daenensis celak. Biomed Res 2016;27: 489-493.

12. Ojo SKS, Ejims-Enukwe O, Esumeh FI. In-vitro antibacterial time-kill assay of phyllanthus amarus and diodia scandens crude extracts on staphylococci isolated from wounds and burns patients. Int J Pharmaceut Sci Invent 2013;2: 9-13.

13. Olajuyigbe OO, Afolayan AJ. In vitro antibacterial and time-kill assessment of crude methanolic stem bark extract of acacia mearnsii de wild against bacteria in shigellosis. Molecules 2012;17: 2103-2118.

14. Appiah T, Boakye YD, Agyare C. Antimicrobial activities and time-kill kinetics of extracts of selected ghanaian mushrooms. Evidence-Based Comp \& Alt 2017;1: 1-15.

15. Yadav A, Yadav M, Kumar S, et al. In Vitro Antibacterial and Time-kill Kinetic Studies. Int J Cur Res 2015;7: 22289-22294.

16. Thammawat S, Sangdee K, Sangdee A. Time-kill profiles and cell-surface morphological effects of crude Polycephalomyces nipponicus Cod-MK1201 myce-lial extract against antibiotic-sensitive and resistant Staphylococcus aureus. Trop J Pharmaceut Res 2017;2: 407-412.

17. Olasunkanmi A, Olasunkanmi OO, Akanbi OE. Studies on the antibacterial potential and time-kill assays of methanol leaf extract of lawsonia inermis (Linn). Asian J Res Med \& Pharmaceut Sci 2017;1: 1-9.

18. Bax HI, Bakker-Woudenberg IAJM, de Vogel CP, et al. The role of the time-kill kinetics assay as part of a preclinical modeling framework for assessing the activity of antituberculosis. Tubercul 2017;105: 80-85.

19. Aiyegoro OA, Afolayan AJ, Okoh AI. In vitro antibacterial time-kill studies of leaves extracts of Helichrysum longifolium. J Med Plant Res 2009;3: 462-467.

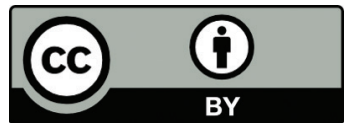

This work is licensed under a Creative Commons Attribution 